\title{
Efficiency of nano-volcanic scoria in the concrete binder
}

\author{
Aref M. al-Swaidani ${ }^{1}$ (i) \\ (c) Springer Nature Switzerland AG 2019
}

\begin{abstract}
The objective of this study is to investigate the efficiency of volcanic scoria when added to the concrete binder at a nano-scale. Nano volcanic scoria (nano-VS) was obtained by grinding a local volcanic scoria for $6 \mathrm{~h}$. Twenty-four concrete mixes with four w/b ratios $(0.4,0.5,0.6$ and 0.7$)$ and six-replacement levels of nano-VS $(0 \%, 1 \%, 2 \%, 3 \%, 4 \%$, and $5 \%)$ have been produced. The investigated concrete properties were the compressive strength, the water penetration depth, the concrete porosity and the chloride ion permeability. Workability of fresh concrete mixes has been also determined. The efficiency factor ( $k$ ) of nano-VS in terms of compressive strength was calculated using the Bolomey equation. Durability indicators have been used to globally evaluate the behavior of nano-VS-based binder concrete versus control concrete. The results revealed that the efficiency factor $(\mathrm{k})$ decreased to some extent when the nano-VS content was bigger than $4 \%$. The calculated durability indicators showed that the nano-VS contents of $3 \%$ and $4 \%$ had approximately the highest indicators values. These indicators would be helpful for concrete mix designers. Some correlations between the investigated properties were derived from the analyzed data. The modification of the microstructure of nano-VS-based cement paste has been observed, as well.
\end{abstract}

Keywords Nano-volcanic scoria · Compressive strength · Concrete permeability · Concrete durability · Efficiency factor

\section{Introduction}

Although there have been many studies on the use of natural pozzolan in literature, there are still limited works on using volcanic scoria (VS) either at micro or nano-scale. The author thinks that no or very little number of studies on the use of nano-VS as cement replacement can be found in literature. Volcanic scoria cones exist in large numbers around the world, such as in Syria, Turkey, Iran and others [1-10]. One may find more details on the use of VS as a substitute for Portland cement, in the chapter recently published by the author [11].

One of the main shortcomings associated with using volcanic scoria at a micro-scale is the reduction of strength at early ages. This reduction could be mainly due to the slowness of the pozzolanic reaction between the glassy phase in volcanic scoria and the $\mathrm{CH}$ released during cement hydration [12]. However, use of nano-particles could be a solution to overcome this disadvantage. Several types of nano-additives such as nano- $\mathrm{SiO}_{2}$, nanoclay, nano- $-\mathrm{Al}_{2} \mathrm{O}_{3}$, nano- $\mathrm{Fe}_{2} \mathrm{O}_{3}$ and carbon nanotubes have recently been used in order to enhance the compressive strength and the concrete durability [13-17]. This enhancement was attributed to the very high fineness and pozzolanic reactivity of the nano-particles [18]. In addition, acting as nucleus, nanoparticles can produce concrete of more compacted microstructure despite of small replacement level [14]. Therefore, it is possible to obtain less porous concrete with high early compressive strength and long service life. In a study carried out by Zhang \& Li [19], enhanced resistance to chloride ion penetration was observed when nano particles, such as nano- $\mathrm{SiO}_{2}$ and nano- $\mathrm{TiO}_{2}$ were added to the mix. They found that the addition of $1 \%$ nano- $\mathrm{SiO}_{2}$ reduced the

Aref M. al-Swaidani, a-swaidani@aiu.edu.sy; aydlswaidan@gmail.com | ${ }^{1}$ Faculty of Engineering, Arab International (Formerly European) University, Damascus, Syria.

SN Applied Sciences (2019) 1:980 | https://doi.org/10.1007/s42452-019-1039-6 
chloride diffusion coefficient by about $18 \%$ when compared with the control concrete. Further, much more reduction was noted when $1 \%$ nano- $\mathrm{TiO}_{2}$ content was added. It was estimated to be more than $30 \%$. They also concluded that the enhanced extent of the resistance to chloride ion penetration of concretes reduces with the increasing content of nano-particles. They attributed the improvement in this resistance to the refinement of pore structure offered by adding such nano particles.

On the other hand, the resistance to sulfate ion attack was significantly enhanced when nano particles were added to the concrete mix. Very high sulfate resisting binder was obtained when PC was blended with only $2 \%$ nano- $\mathrm{SiO}_{2}[20,21]$. Singh et al. [22] also reported similar results when $5 \%$ nano-silica was added as cement replacement. However, it is important to mention that nanoparticles have a tendency to agglomerate when using at high dosages (i.e. more than $3 \%$ by weight) in the mix $[13,14,23]$. The aggregation forms weak zones and consequently prevents the formation of homogenous hydrate microstructure. Therefore, the optimum dosage of nano-VS should be examined before its exploitation in the field of concrete industry.

Furthermore, adding nanoparticles as partial cement replacement may markedly modify the rheological properties of pastes and consequently influences the workability of mortars and fresh concrete mixes [24, 25]. In their study, Nazari \& Riahi [24] found that the addition of $\mathrm{TiO}_{2}$ nanoparticles reduced the concrete workability. This reduction was obvious in the concretes of higher nano- $\mathrm{TiO}_{2}$ content, i.e. $3 \%$ and more. The increase in surface area due to the added extremely fine particles may justify this result [24]. Sneff et al. [25] also found that fluidity and spreading of the cement paste and mortar decreased as the nano-silica content increased. However, Ferraris et al. [26] argue that the relationship between the rheology of cement paste and that of concrete has not been completely established. This could be attributed to the fact that the rheology of cement paste is typically measured under conditions different from those encountered in concrete [26].

Many published studies on the use of nano-additives have just investigated the properties of concrete after 7 and 28 days curing $[27,28]$. However, properties of concretes containing nano-particles, such as compressive strength, water permeability, chloride penetrability and porosity have not widely been investigated at later ages (i.e. 90 and 180 days). Therefore, the present paper attempts to highlight some different properties of concrete made with binder containing nano-VS after five curing ages $(2,7,28,90$ and 180 days). The investigated properties are:

(1) One mechanical property; i.e. the compressive strength (CS).

(2) Three durability-related properties; i.e. water permeability (WP), porosity (PO) and chloride ion penetrability (CIP).

(3) In addition to the above mentioned properties, the slump test was carried out for all fresh concrete mixtures in order to determine the effect of adding nanoVS on concrete workability.

Six levels of nano-VS replacement and four different $\mathrm{w} / \mathrm{b}$ ratios have been used. The efficiency factor $(k)$ was evaluated considering the compressive strength. On the other hand, the durability indicators were evaluated using the compressive strength and the concrete properties related to its durability. In addition, some relationships between different properties of concrete have been extracted, and some prediction correlations have been derived.

The importance of the current study can be summarized in the following points:

(1) Use of nano-technology in the field of concrete industry can be considered the first of its kind in our country. It is true that the replacement levels of nano-VS are not high enough to reduce $\mathrm{CO}_{2}$ emissions significantly, but blending nano-VS with a high content of
Fig. 1 Particle size distribution of VS at different scales with some photos (VS as received, the ball mill and nano-VS)

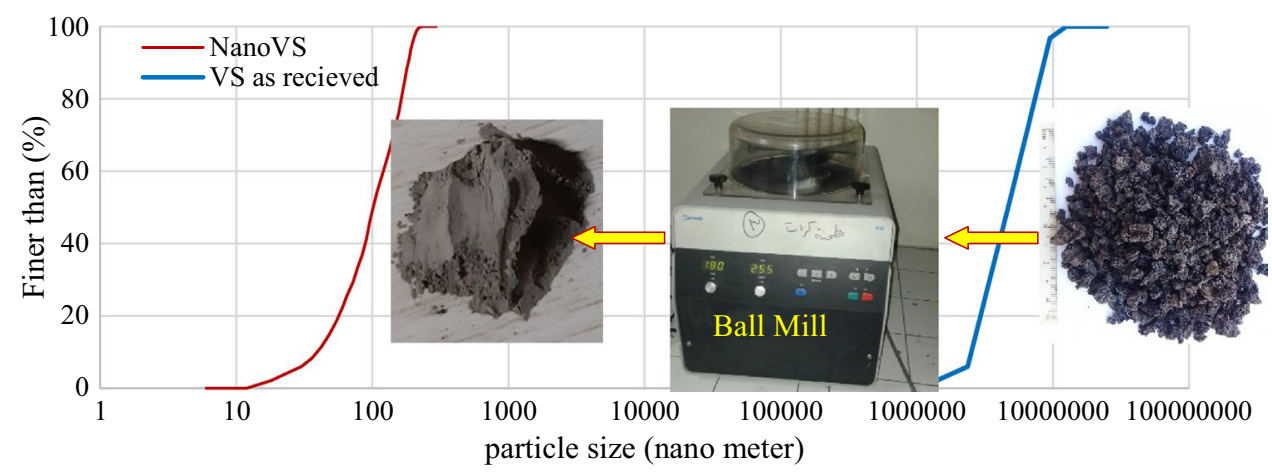


Fig. 2 SEM (a), AFM (b) micrographs of nano-VS with EDS (c) and XRD (d) analysis (An: Anorthite, Dp: Diopside, Fu: Fujasite, Ca: Calcite, Fo: Forstrite)

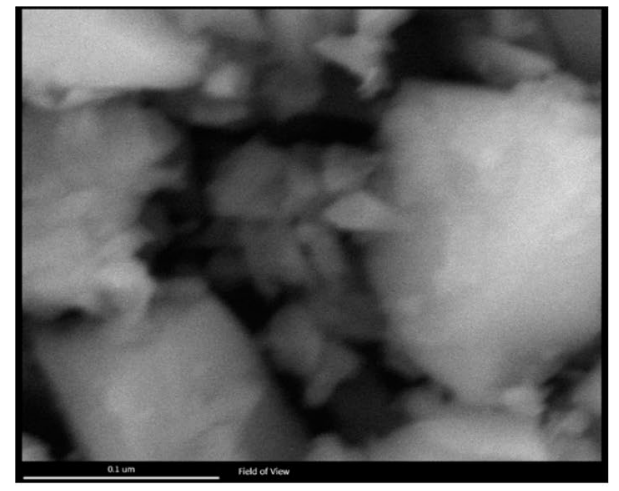

(a)

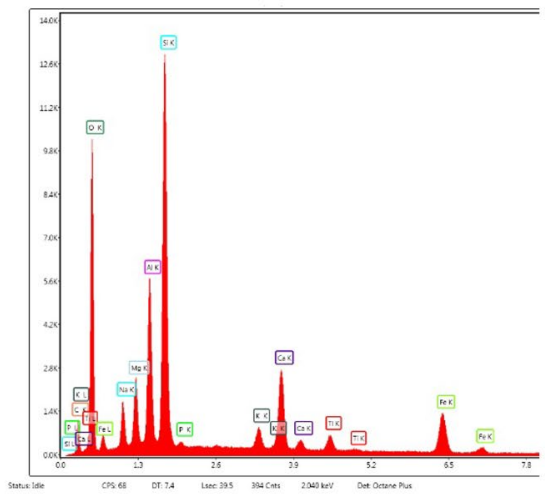

(c)

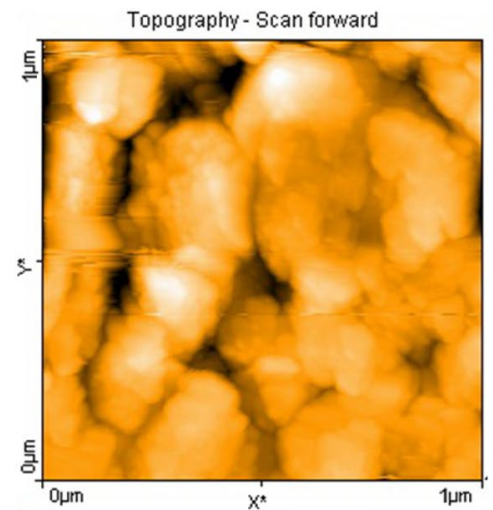

(b)

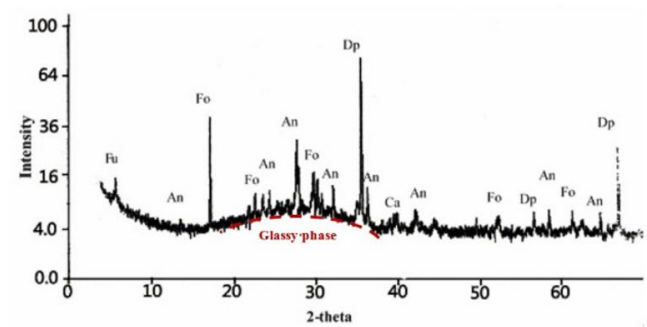

(d)

Fig. 3 Grading curves of aggregates used in the experimental part

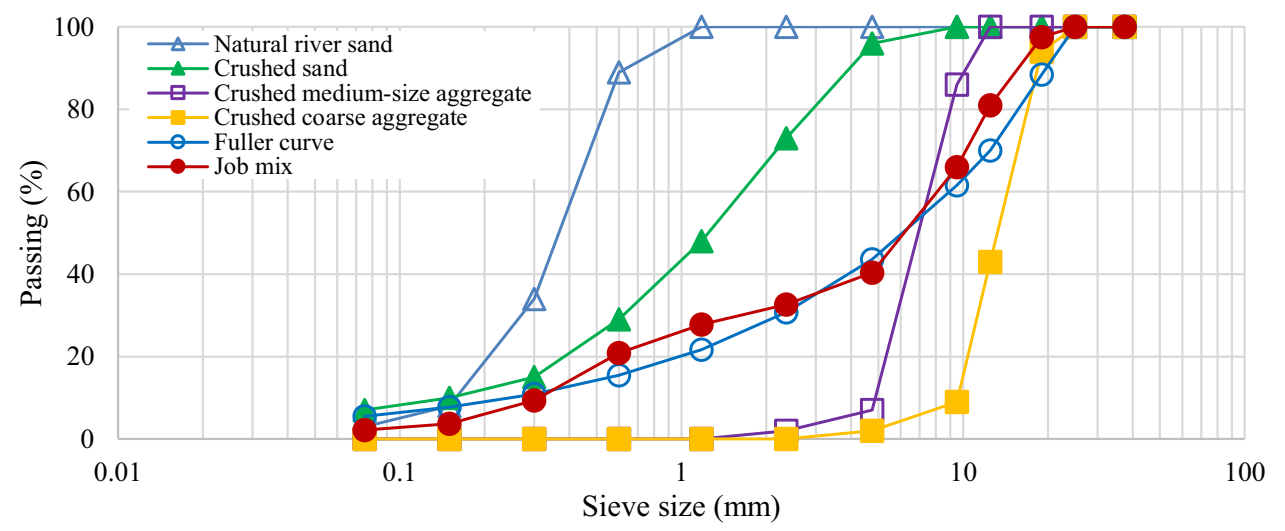

micro-VS could be a promising approach, particularly in the rebuilding stage in Syria.

(2) The encouraging results obtained by the author et al. $[1,12]$ on using Syrian micro-VS, as a partial substitute for cement, were behind the current study. The replacement levels, which were up to $35 \%$, can achieve a remarkable reduction in $\mathrm{CO}_{2}$ emissions and energy consumption.

(3) Studies on using nano-natural pozzolan, particularly of volcanic origin, in making concrete mixtures are too limited. Therefore, investigating the effect of
nano-VS on the concrete properties may be of much benefit to the literature.

(4) The obtained results may be useful for designers of nano-VS-containing concrete mixes. Hence, they can determine the optimum content of nano-VS, which is similar to the investigated one. This optimum content fulfils the best performance of the concrete in terms of compressive strength and durability. 
Table 1 Slump test results of the concrete mixes prepared without superplasticizer (measured in accordance with ASTM C143-2000)

\begin{tabular}{lllll}
\hline Concrete mixes & \multicolumn{4}{l}{$\begin{array}{l}\text { Slump test results } \pm \text { standard deviation }(\mathrm{SD}) \\
\text { values }(\mathrm{mm})\end{array}$} \\
\cline { 2 - 5 } & $\mathrm{w} / \mathrm{b}=0.4$ & $\mathrm{w} / \mathrm{b}=0.5$ & $\mathrm{w} / \mathrm{b}=0.6$ & $\mathrm{w} / \mathrm{b}=0.7$ \\
\hline Nano-VS0 & $*$ & $84 \pm 2.2$ & $126 \pm 2.4$ & $180 \pm 3.6$ \\
Nano-VS1 & $*$ & $82 \pm 1.7$ & $126 \pm 3.1$ & $177 \pm 1.9$ \\
Nano-VS2 & $*$ & $78 \pm 2.3$ & $123 \pm 2.2$ & $175 \pm 2.5$ \\
Nano-VS3 & $*$ & $77 \pm 2.0$ & $119 \pm 1.8$ & $173 \pm 2.6$ \\
Nano-VS4 & $*$ & $75 \pm 1.4$ & $120 \pm 2.0$ & $169 \pm 2.3$ \\
Nano-VS5 & $*$ & $67 \pm 2.1$ & $114 \pm 2.7$ & $161 \pm 3.1$ \\
\hline
\end{tabular}

*The slump test results were less than $25 \mathrm{~mm}$

\section{Efficiency factor and durability indicators of volcanic scoria}

The concept of the efficiency factor, $k$, was first proposed by Smith [29] as the basis of his rational proportioning approach for fly ash concrete. Originally, the k factor was defined as the mass of a supplementary cementing material that makes the same contribution to the strength of concrete as a unit mass of ordinary Portland cement (OPC). According to Thomas and Matthews' study [30], $1 \mathrm{~kg}$ of fly ash makes the same contribution to the 28-day strength of concrete as $0.32 \mathrm{~kg}$ of OPC; i.e. $\mathrm{k}=0.32$. Babu and Rao [31] have suggested that "k-value" of fly ash can be suggested as 0.25 for replacements up to $25 \%$. Studies on silica fume, on the other hand, have shown that $k$ values range from 2 to 4 [32]. Pozzolan can be considered more efficient than OPC when $k>1$. OPC saving is possible in such a case. On the other hand, pozzolan can be considered less efficient than OPC when $k<1$. More pozzolan content should be used to achieve the required target strength in such a case. European standard for concrete (EN 206-1:2000) has reported only the efficiency factor, $k$, for fly ash and silica fume. The maximum percentage of fly ash to be incorporated when the $k$ value is concerned is fly ash/cement $\leq 0.33$ by mass. German Standards DIN 1045 recommend a k value of 0.3 for replacement levels between 10 and $25 \%$. British Code $(B C)$ refers to a $k$ value of 0.4 for replacements up to $0.25 \%$. No $k$ value was given for natural pozzolan either at micro- or nano-scale in the European Standard, and little data are available on its efficiency factor at microscale in the literature.

Tchamdjou et al. [33] have studied this term in order to evaluate four volcanic scoria samples of different colors (black, dark red, red and yellow). 28-days compressive strength, sorptivity and carbonation were investigated in their study. Their result showed that $15 \%$ dark red VS- and $15 \%$ red VS-based mortars had a similar durability index versus control mortar when strength, sorptivity and carbonation depth were taken into account. In addition, the mortar with 15\% dark red VS was better than control mortar when only strength and carbonation depth were taken into account.

\section{Materials and methods}

A local volcanic scoria quarried from the south of Syria was used in the experimental part. Its main oxides (\%) are as follows: $\mathrm{SiO}_{2}: 45 ; \mathrm{CaO}: 9 ; \mathrm{Al}_{2} \mathrm{O}_{3}: 17 ; \mathrm{Fe}_{2} \mathrm{O}_{3}: 9 ; \mathrm{MgO}: 8$; alkalis

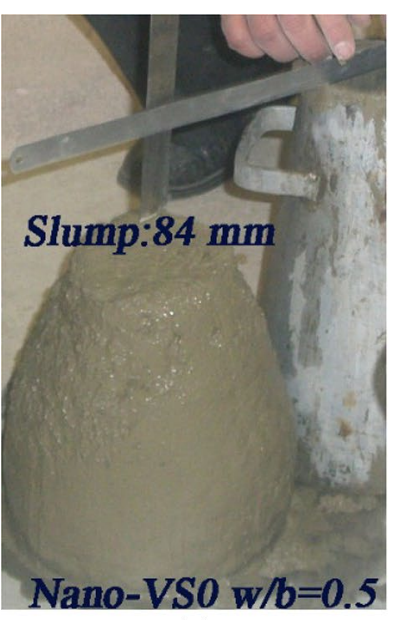

(a)

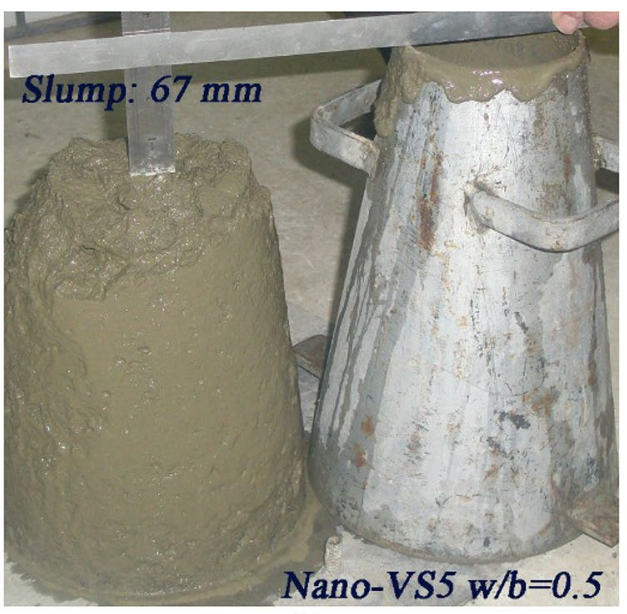

(b)

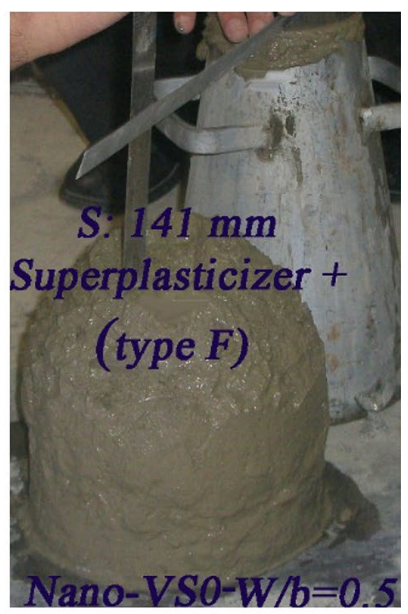

(c)

Fig. 4 Slump test photos of some fresh concrete mixes ( $\mathbf{a}$ and $\mathbf{b}$ concrete mixes made with no superplasticizer and $\mathbf{c}$ with superplasticizer added) 
Fig. 5 Compressive strength versus curing age for nano-VSbased concretes made with different $w / b$ ratios (SD values ranged from 0.25 to $1.41 \mathrm{MPa}$ )

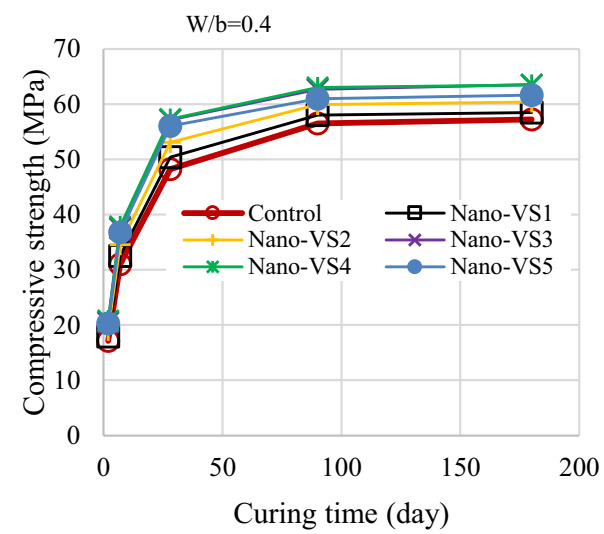

(a) Nano-VS $(\mathrm{w} / \mathrm{b}=0.4)$

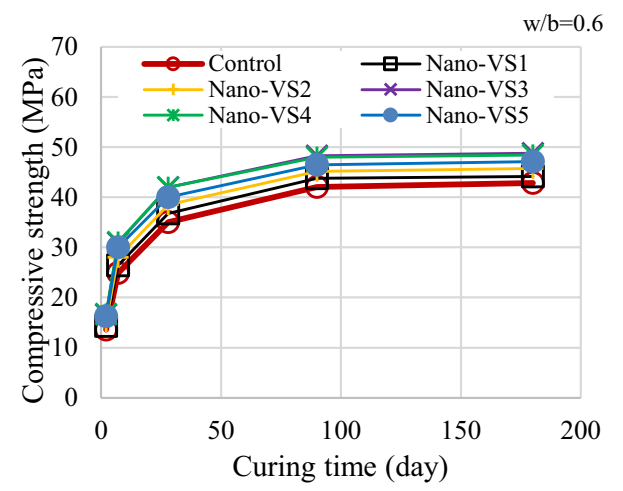

(c) Nano-VS $(\mathrm{w} / \mathrm{b}=0.6)$

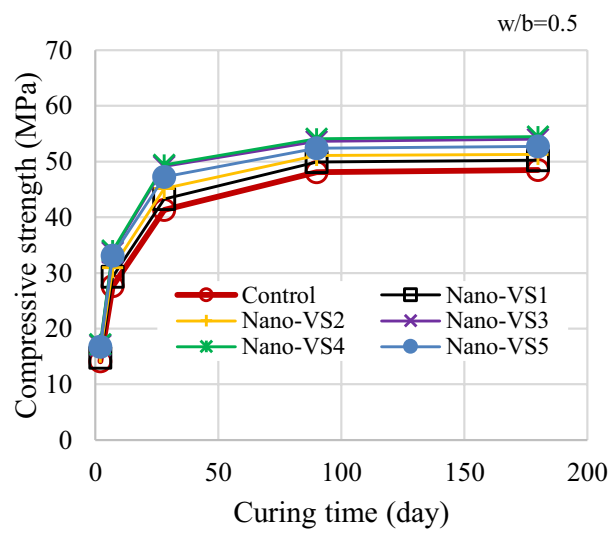

(b) Nano-VS (w/b=0.5)

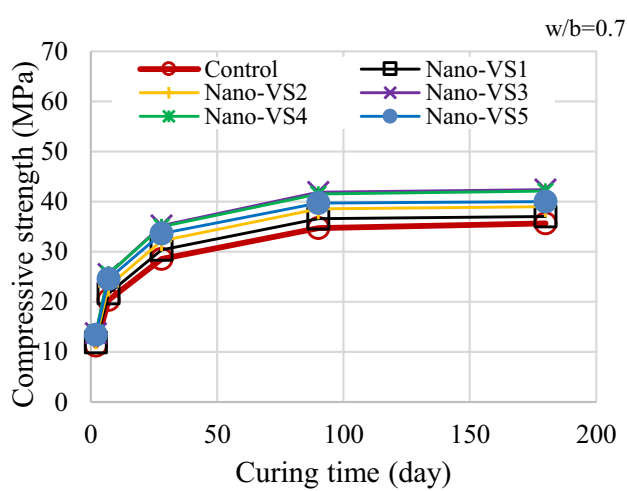

(d) Nano-VS $(\mathrm{w} / \mathrm{b}=0.7)$
$\left(\mathrm{Na}_{2} \mathrm{O} \& \mathrm{~K}_{2} \mathrm{O}\right): 4.5$. In addition, its reactive silica content $\left(\mathrm{SiO}_{2 \text { reactive }}\right)$ has been determined in accordance with EN $196-2$, and its value was about $41 \%$. The particle size distribution of nano-VS as compared with VS-as received is illustrated in Fig. 1. SEM and AFM micrographs of the nano-VS associated with EDS and XRD analysis are shown in Fig. 2. After 6-h grinding, nano-sized VS particles with a relatively round shape were obtained, as can be clearly seen in Fig. 2a, b. The prolonged grinding may form a highly reactive material on the surface of the mineral particles. In addition, Fig. 2c, d shows the chemical and mineralogical composition of the investigated VS obtained by EDS and XRD techniques, respectively.

Nano-VS has been added at six replacement levels, i.e. $(0 \%, 1 \%, 2 \%, 3 \%, 4 \%$ and $5 \%)$. Four $\mathrm{w} / \mathrm{b}$ ratios, i.e. $0.4,0.5$, 0.6 and 0.7 have been used in the current work. Aggregates used in the concrete mixes were crushed dolomite stone (Specific gravity; $S G=2.82$ ) and natural river sand ( $S G=2.69)$. Their grading curves are illustrated in Fig. 3 . The binder content was $350 \mathrm{~kg} / \mathrm{m}^{3}$. The method of mixing suggested by Jo et al. [27] was adopted, with some minor modification, in the current study. The five steps modified method can be summarized as follows:
(1) Nano-VS was mixed with water using ultra-sonic mixer "Bandelin Sonorex model" for 3 min to get a uniform dispersion of nano-VS particles.

(2) Cement and aggregates were thoroughly mixed in a dry form for $2 \mathrm{~min}$ in a concrete rotary mixer.

(3) The mixture of nano-VS and mixing water was poured gradually.

(4) The superplasticizer "type F" (if applicable) was added to get the desired slump $(150 \pm 25 \mathrm{~mm})$.

(5) The mixture was allowed to rest for $1 \mathrm{~min}$. Any solids adhered to the internal surface of the mixer were reblended in the concrete mixer. Then, the mixture was mixed for another 2 min period.

Slumps of the fresh concrete mixes prepared without superplasticizer were measured immediately, in accordance with ASTM C143-2000, to evaluate the concrete workability. The results are illustrated in Table 1 and Fig. 4.

Four properties have been particularly investigated; i.e. compressive strength (CS), water permeability (WP), porosity (PO) and chloride ion penetrability (CIP). These investigations or tests have been carried out after five different curing ages i.e. $(2,7,28,90$ and 180 days) in accordance 
Fig. 6 WP results accompanied by the error bars of the concretes made with different $\mathrm{w} / \mathrm{b}$ ratios and cured for five different curing ages

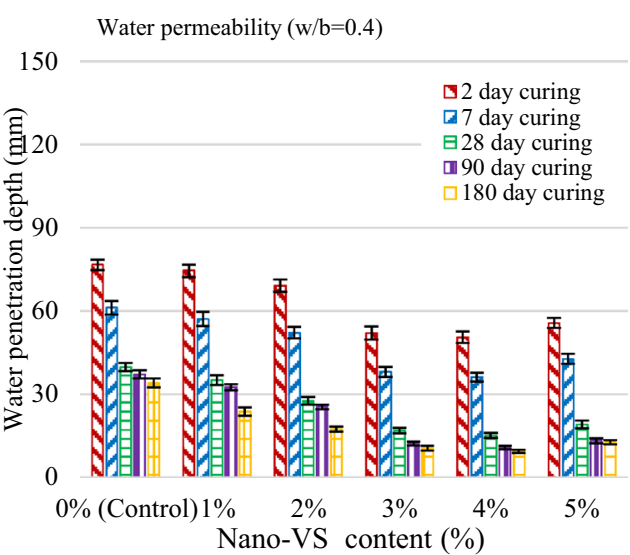

(a) Nano-VS $(\mathrm{w} / \mathrm{b}=0.4)$

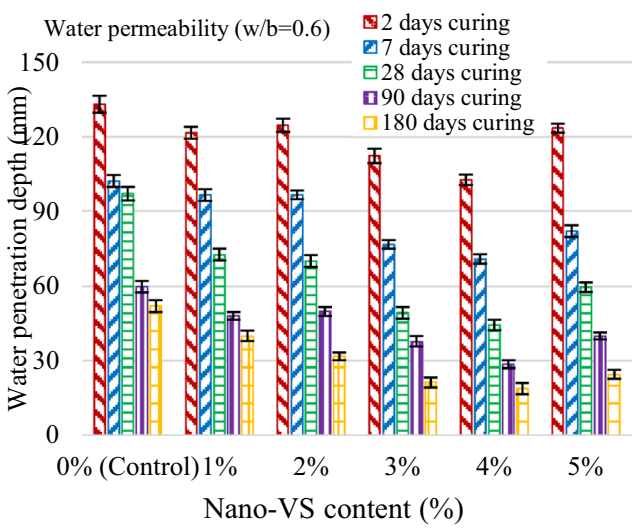

(c) Nano-VS $(\mathrm{w} / \mathrm{b}=0.6)$

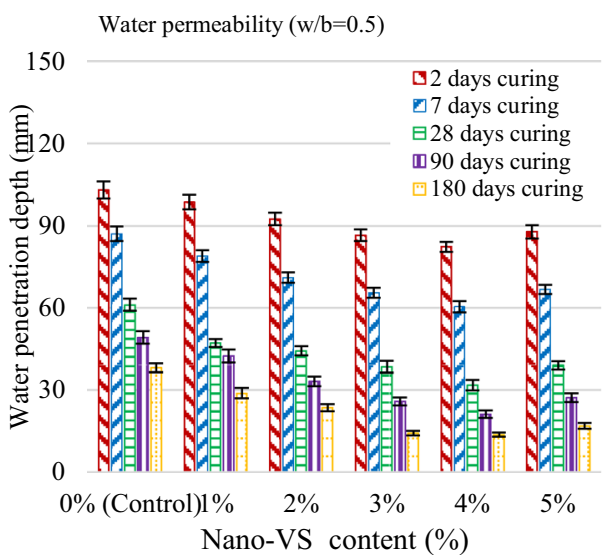

(b) Nano-VS $(\mathrm{w} / \mathrm{b}=0.5)$

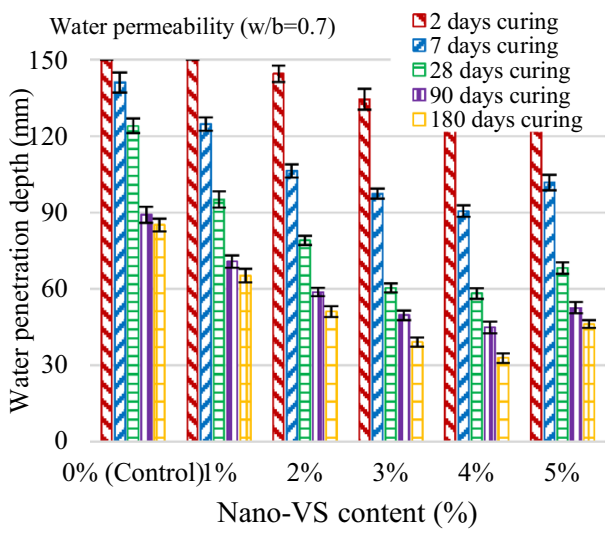

(d) Nano-VS (w/b=0.7) with ISO 4012, EN 12390-8, RILEM CPC 11.3 and ASTM C1202, respectively.

The compressive strength results and Bolomey strength equation, Eq. 1, have been employed in determining the efficiency factors of nano-VS on the concrete compressive strength. Tchamdjou et al. [33], Pekmezci and Akyuz [34] and Kaid et al. [35] have used the following Bolomey equation, Eq. 1, to determine the efficiency factor of natural pozzolan

$f_{c}=k_{b}\left(\frac{C+k \times V S}{W}-0.5\right)$

where $f_{\mathrm{c}}$ is the concrete compressive strength (MPa), $C$ is the cement content in the concrete $\left(\mathrm{kg} / \mathrm{m}^{3}\right), W$ is the water content, VS is the volcanic scoria content $\left(\mathrm{kg} / \mathrm{m}^{3}\right)$ and $K_{\mathrm{b}}$ is the Bolomey coefficient. $K_{\mathrm{b}}$ is calculated from the concrete mix with zero content of nano-VS, $\mathrm{k}$ is the efficiency factor.

In addition, the durability indicators were calculated using Eq. 2 [33]

$D I=\left(\frac{f_{c i}}{f_{c}}-1\right)-\left(\frac{\operatorname{Per}_{i}}{\operatorname{Per}_{c}}-1\right)$ where $f_{c i} / f_{c} \&$ Per $_{i} /$ Per $_{c}$ are the relative compressive strength and the relative permeability-related property of VS-based binder concretes; $f_{c}$ and $\mathrm{Per}_{c}$ are the compressive strength and permeability-related property of the control concrete. The expression "- $\left(\frac{P r_{i}}{P e r_{c}}-1\right)$ " takes into account the negative effect of permeability-related property on the durability. Concrete with positive $D I$ is considered better than control concrete from durability point-of-view.

\section{Results and discussion}

\subsection{Concrete workability}

Figure 4 and Table 1 illustrate the results of fresh concrete slumps determined following the standard test method specified by ASTM C143. As shown in Table 1, all concretes containing nano-VS had lower workability when compared with those of control concrete at all $\mathrm{w} / \mathrm{b}$ ratios. The reductions in slump values were clearly observed in all concrete mixes, particularly when nano-VS was added at high replacement levels, i.e. 5\%. They ranged from 11 
Fig. 7 Relative WP results of the concretes made with different $\mathrm{w} / \mathrm{b}$ ratios and cured for five different curing ages

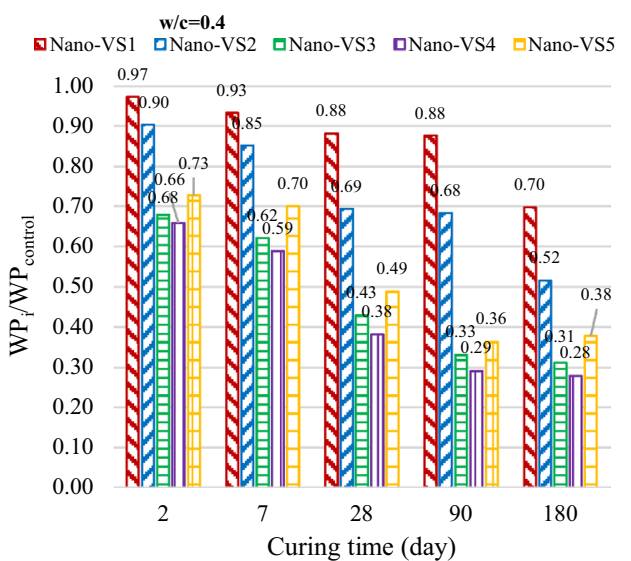

(a) Nano-VS $(\mathrm{w} / \mathrm{b}=0.4)$

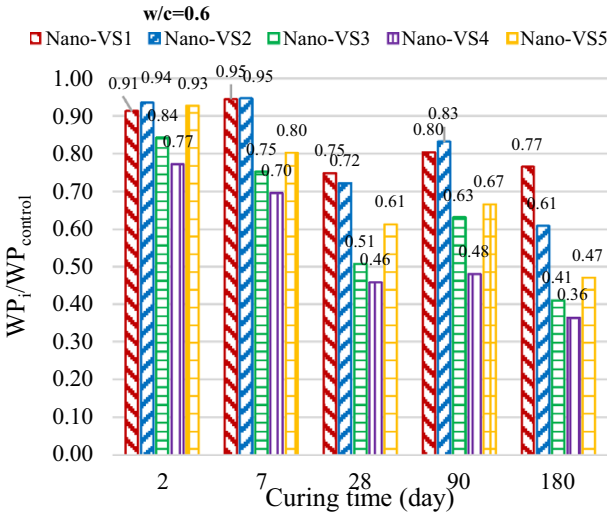

(c) Nano-VS $(\mathrm{w} / \mathrm{b}=0.6)$

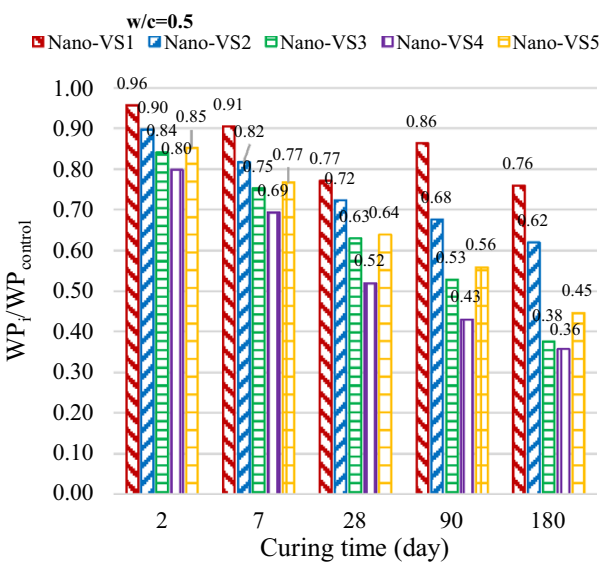

(b) Nano-VS $(\mathrm{w} / \mathrm{b}=0.5)$

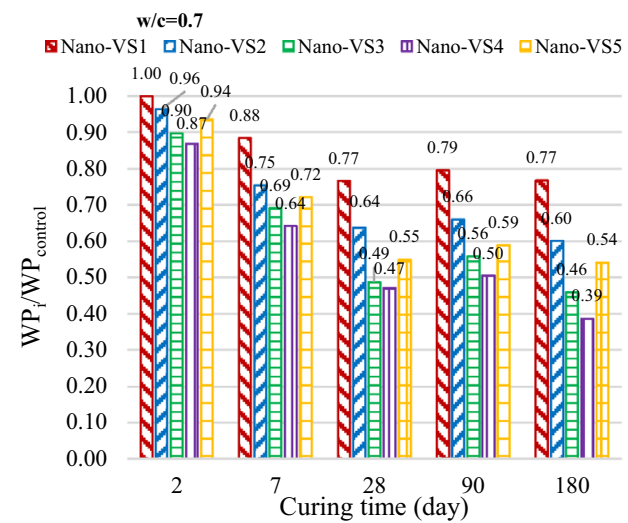

(d) Nano-VS (w/b=0.7) to $20 \%$ in the nano-VS5-based concretes prepared at $\mathrm{w} / \mathrm{b}$ ratios of 0.7 and 0.5 , respectively. These results are in well agreement with that reported in literature $[24,36,37]$. The lower workability obtained when using nano-VS, particularly at high replacement level, i.e. $5 \%$, can be attributed to the increase of surface area of the binder after adding nano-VS particles that need more water for wetting the binder nanoparticles $[24,38]$. In addition, the ultra-high specific area and high surface energy of the nano-VS particles will result in attraction of each other. The more the number of nano-VS particles the higher their capability to agglomerate in the concrete mix [36].

\subsection{Development of concrete compressive strength}

Figure 5 illustrates the results of compressive strength development with curing age. As shown in Fig. 5 all concretes containing nano-VS have higher compressive strengths when compared with those of control concrete at all $\mathrm{w} / \mathrm{b}$ ratios. In addition, the compressive strength of the concrete incorporating nano-VS was significantly enhanced, particularly at early ages. This improvement can be attributed to the pozzolanic and filling effects of nano-VS. Further, nano-VS particles were not only acting as a filler, but also could be act as an activator to promote hydration if the nano-particles were uniformly dispersed. In contrast to the results of Hakamy et al. [14] and Oltulu \& Sahin [16], the addition of nano-VS beyond $1 \%$ by weight into binder has not adversely affected the compressive strength. This can be ascribed to the adopted mixing method by which the nano-VS particles might be well dispersed and no or limited agglomeration has encountered. The compressive strength of the concretes was found to increase as the nano-VS content increased from 1 to $4 \%$. However, a little decrease in strength was observed when nano-VS content increased from 4 to $5 \%$. This could be due to some agglomeration, which may occur when this relatively high nano-VS content is used.

\subsection{Properties of concrete permeability}

Figures $6,7,8,9,10$ and 11 shows the results of permeability-related properties for all percentage of nano-VS, curing ages and $\mathrm{w} / \mathrm{b}$ ratios. For all types of concrete mixes, WP increased with the increase of $\mathrm{w} / \mathrm{b}$ ratio, as clearly seen in Fig. 6. WP moved from low to high when $\mathrm{w} / \mathrm{b}$ increased from 0.4 to 0.7 , according to Neville's grading [39]. In 
Fig. 8 PO results of the concretes made with different $\mathrm{w} / \mathrm{b}$ ratios and cured for five different curing ages

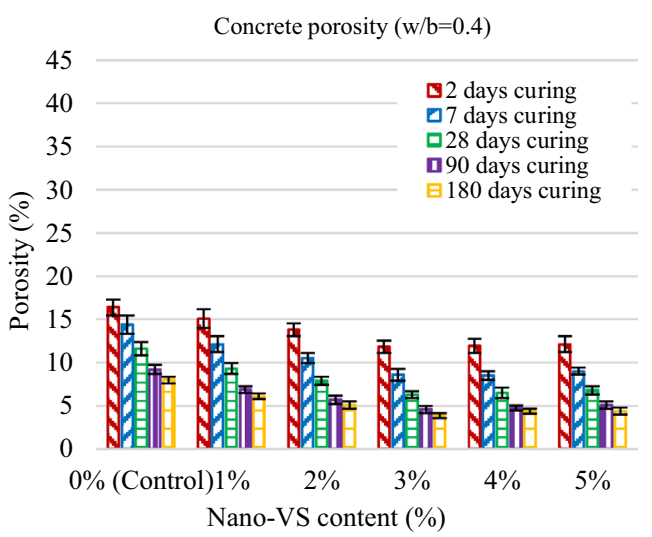

(a) Nano-VS $(\mathrm{w} / \mathrm{b}=0.4)$

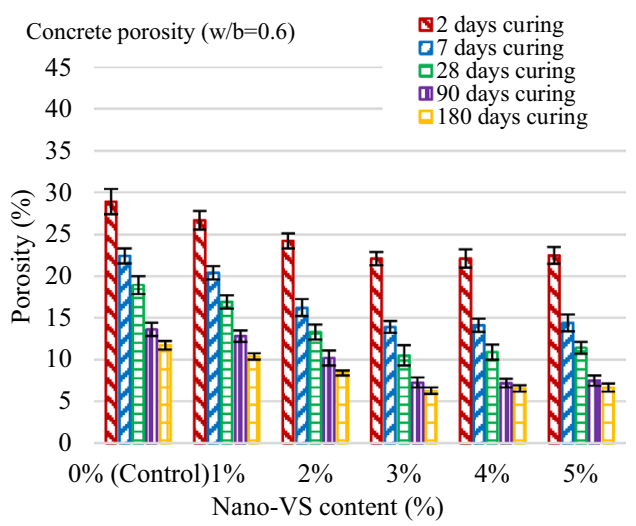

(c) Nano-VS $(\mathrm{w} / \mathrm{b}=0.6)$

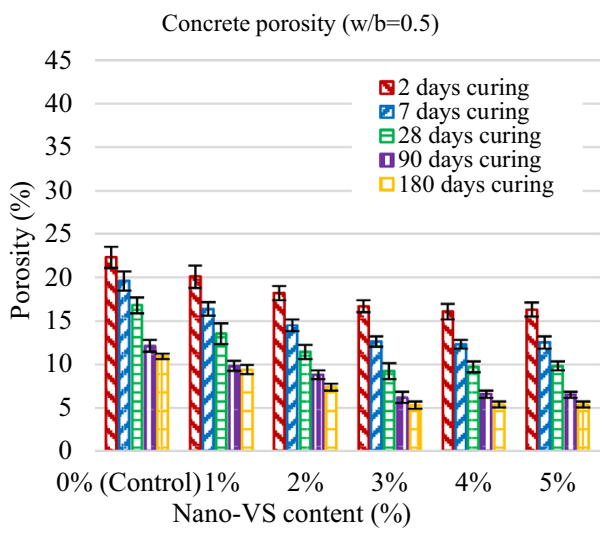

(b) Nano-VS (w/b=0.5)

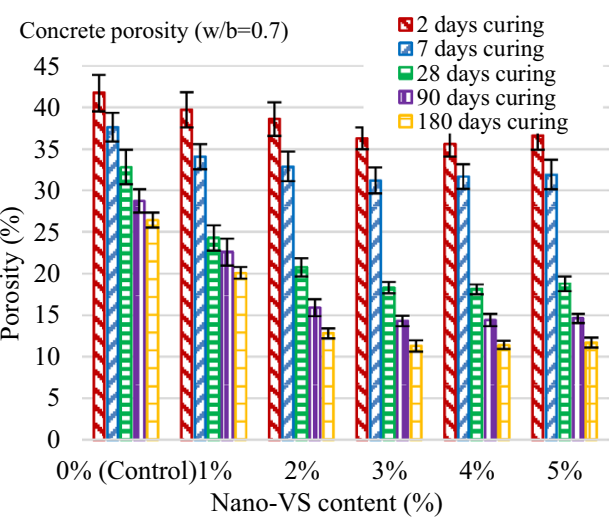

(d) Nano-VS (w/b=0.7) addition, all nano-VS-based concrete mixtures prepared with $\mathrm{w} / \mathrm{b} \leq 0.5$ can be classified as "low permeable" when cured for 28 days or as "impermeable even under severe conditions" when cured for 90 days or longer. On the other hand, no concrete mix can be classified as "impermeable" when prepared with $w / b=0.7$. Further, WP was significantly reduced, even at early ages, when nano-VS of content $\geq 3 \%$ was used. This can be due to the extremely small size of nano-VS particles, which can fill the pores and their very high reactivity, which leads to a more compacted matrix with more cementing compounds [40]. WP results of nano-VS-based concrete relative to those of control concrete are shown in Fig. 7. It is clearly seen in Fig. 7, that at all $\mathrm{w} / \mathrm{b}$ ratios, an increase in nano-VS leads to a decrease in WP values, particularly when nano-VS content was $\leq 4 \%$. However, a little increase in WP values was noted when nano-VS content increased from $4 \%$ to $5 \%$. This is due to the probability of the agglomeration of nano-VS particles added at higher percentages, i.e. $5 \%$.

Similar trend was observed in both porosity and chloride ion penetrability results, Figs. 8, 9, 10 and 11. However, it is worthwhile to note that when moving from 4 to $5 \%$ nano-VS contents, the relative WP results were not in the same trend when compared with those of CIP. On the one hand, the difference in WP properties between the mixtes with $4 \%$ and $5 \%$ is noticeable for the higher $\mathrm{w} / \mathrm{b}$ ratios. For instance, after 7 days curing, the relative WP results for $4 \%$ nano-VS- and $5 \%$ nano-VS-based mixes were 0.59 \& 0.7 and $0.64 \& 0.72$ when $w / b$ ratio changed from 0.4 to 0.7 , respectively. On the other hand, the difference in CIP properties is more obvious for the lower $\mathrm{w} / \mathrm{b}$ ratio. For instance, after 7 days curing, the relative CIP results for $4 \%$ nano-VS- and 5\% nano-VS-based mixtures were 0.32 $\& 0.51$ and $0.57 \& 0.66$ when $\mathrm{w} / \mathrm{b}$ ratio changed from 0.4 to 0.7 . The explanation of these obtained results needs further investigation. However, the different transport mechanisms involved in the water permeability test and the chloride ion penetration test may justify this difference at present time [41].

Figure 12 shows the correlations among the permeability properties of the investigated concretes. Definite correlations with regression coefficients $\left(R^{2}\right)$ of more than 0.85 , were noted among these properties, such that knowledge of one property can be helpful for estimating the other. According to the Montgomery \& Peck [42]' grading, the relationship can be labelled excellent when $R^{2}$ is equal or bigger than 0.85 . More parameters such as concrete aggregate type, volcanic scoria type and other curing 
Fig. 9 Relative PO results of the concretes made with different $\mathrm{w} / \mathrm{b}$ ratios and cured for five different curing ages

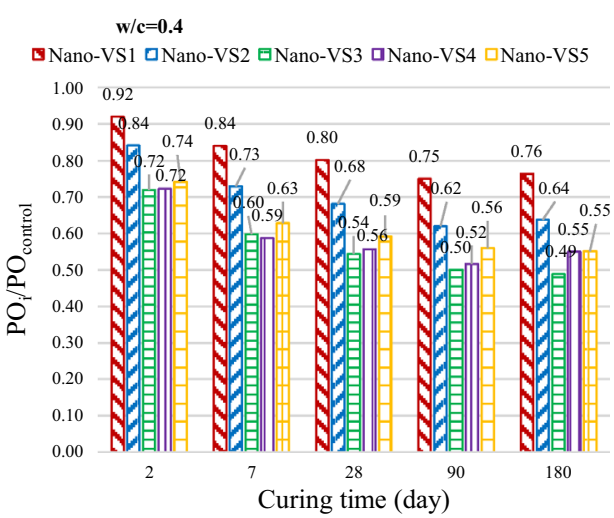

(a) Nano-VS (w/b=0.4)

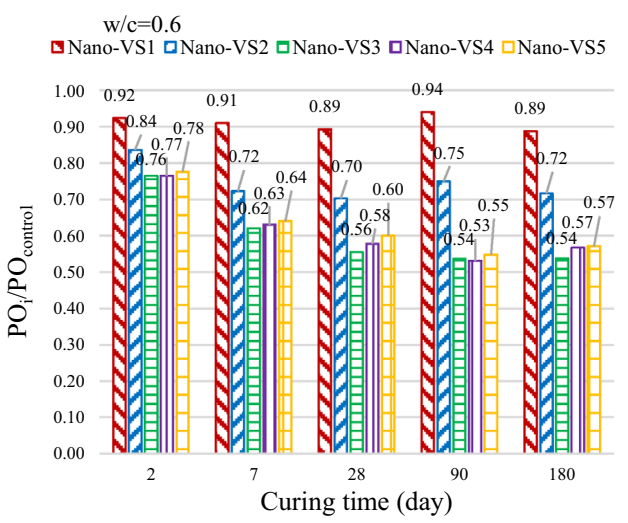

(c) Nano-VS (w/b=0.6)

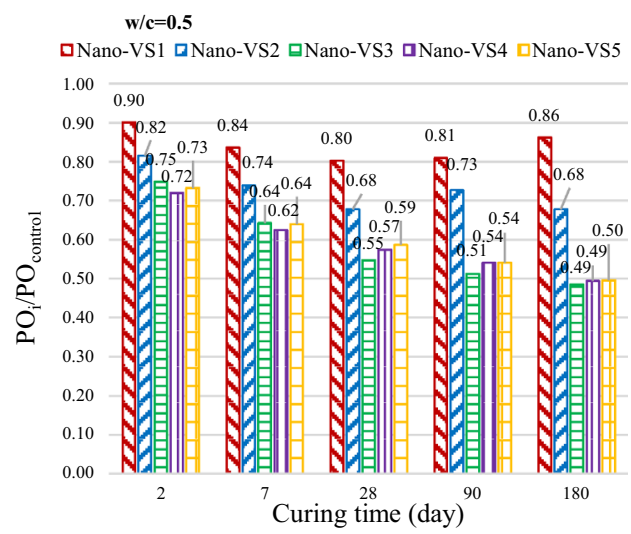

(b) Nano-VS $(\mathrm{w} / \mathrm{b}=0.5)$

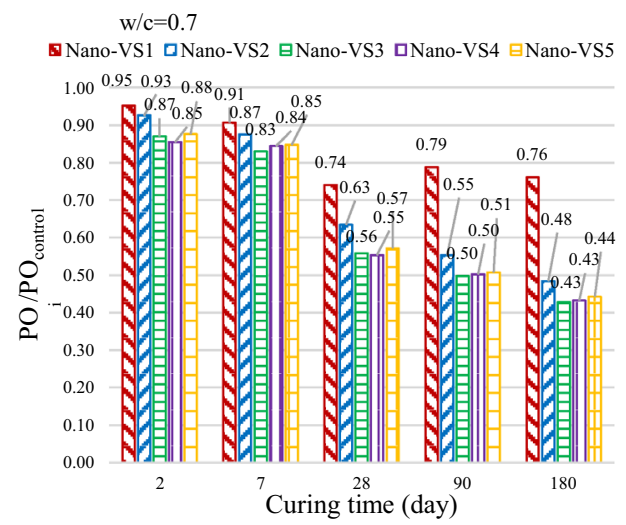

(d) Nano-VS (w/b=0.7) conditions could be further incorporated for developing similar relationships.

\subsection{Efficiency factor and durability indicator}

The efficiency factors of nano-VS were calculated for each replacement level using Bolomey equation. Figure 13 illustrates the evolution of efficiency factors, $k$, for all mixes cured for 28 days. As seen in Fig. 13, with increasing nano-VS content, up to $4 \%$, the efficiency of nano-VS tends to increase, and beyond this replacement level, k-value tends considerably to decrease. This can be attributed to some occurring agglomeration of these extremely fine particles at this level of replacement. In addition, the best k-value was noted when nano-VS was added at $3 \%$. K-values of about 5.8 (irrespective of the $\mathrm{w} / \mathrm{b}$ ratio) were recorded. This argues that nano-VS, because of its very fineness and its very high reactivity, was much more efficient than OPC. Further, no clearly different behavior was observed when $\mathrm{w} / \mathrm{b}$ ratio varied.

Based on the statistical analysis, an equation to estimate the efficiency factor ( $k$ ) when considering two variables, i.e. curing age and nano-VS content can be written as follows:
$K=\left(\alpha_{1} \times \mathrm{NVS}+\alpha_{2}\right) \times \operatorname{lnt}+\alpha_{3} \times \mathrm{NVS}+\alpha_{4}$

where $k$ is the efficiency factor; NVS is the percentage of nano-VS; $t$ is the curing age (day); $a_{1}, a_{2}, a_{3}$ and $a_{4}$ are constants. Based on the regression analysis of the obtained efficiency factors, the constants have been extracted. The best-fit constants $a_{1}, a_{2}, a_{3}$ and $a_{4}$ and the regression coefficients $\left(R^{2}\right)$ of the relationship between the experimental and the calculated values are depicted in Table 2. The results indicated significant relationships between the nano-VS efficiency factor and the curing age with different contents of nano-VS. The derived equation for predicting the efficiency factor of VS can be fruitfully employed by the concrete mix designers.

Durability indicator values when all investigated properties were taken into account were calculated according to the general formula $\mathrm{nr}$ (2) and illustrated in Fig. 14. Figure 14 shows that almost nano-VS4-based cement concretes of $w / b \geq 0.6$ exhibited the highest $D I$ values. This means that these concretes performed the best ones when $w / b$ was equal or more than 0.6 , when the compressive strength and all permeability-related properties were taken into consideration. The highest positive DI values were recorded when $3 \% \leq$ nano-VS content $<5 \%$. This unexpected result can be explained as follows: Increasing 
Fig. 10 CIP results accompanied by the error bars of the concretes made with different $\mathrm{w} / \mathrm{b}$ ratios and cured for five different curing ages (The test was stopped when the temperature of the cell's solution reached values of about $80^{\circ} \mathrm{C}$, see photos above. Results of 14,000 Coloumbs were recorded for these highly penetrable concrete specimens. Thus, no standard deviation was calculated)

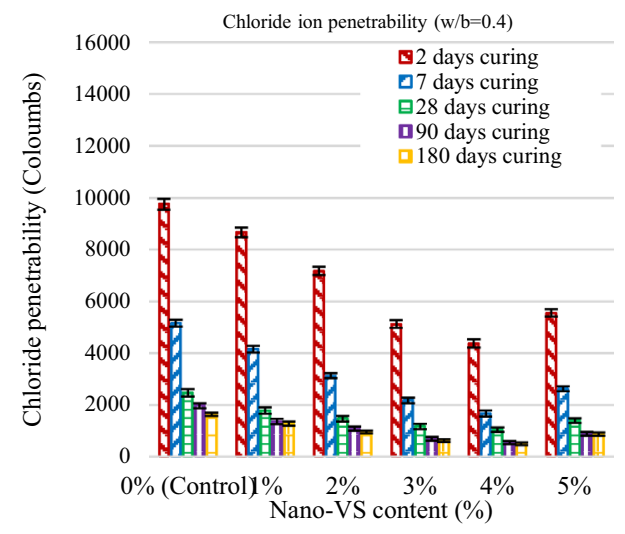

(a) Nano-VS $(\mathrm{w} / \mathrm{b}=0.4)$

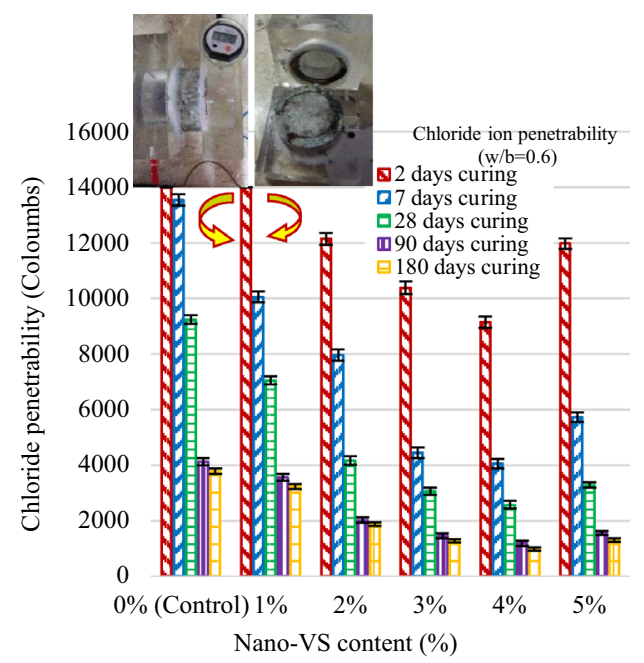

(c) Nano-VS $(\mathrm{w} / \mathrm{b}=0.6)$

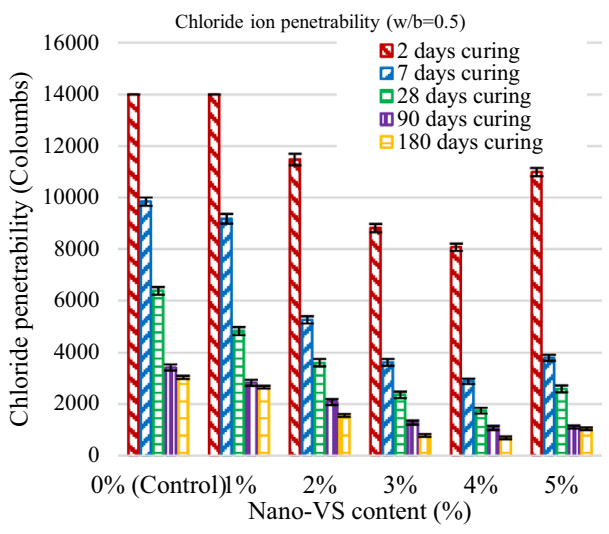

(b) Nano-VS $(\mathrm{w} / \mathrm{b}=0.5)$

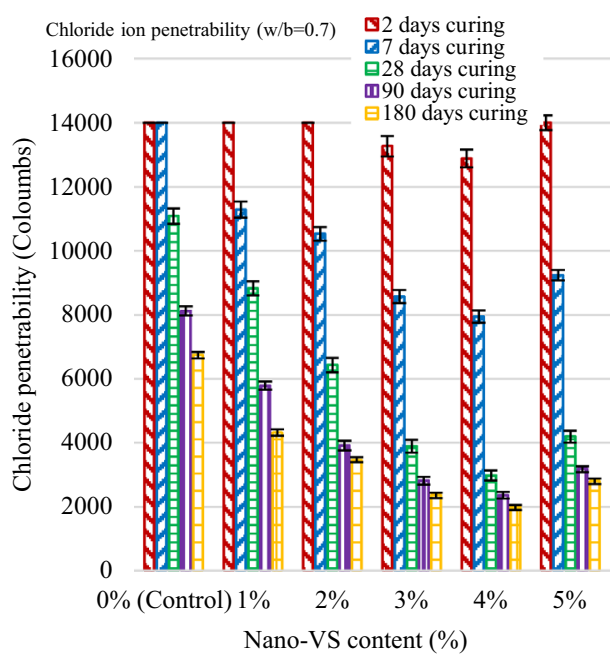

(d) Nano-VS $(\mathrm{w} / \mathrm{b}=0.7)$ the $\mathrm{w} / \mathrm{b}$ ratio of a concrete mix results in a larger inter-particle spacing between cement grains and thus formation of more voids can be expected. In the concrete mix prepared with $\mathrm{w} / \mathrm{b}=0.4$, fewer voids can be detected within the cement matrix. On the other hand, the mix prepared with $\mathrm{w} / \mathrm{b}$ of 0.6 or more will have higher porosity. Therefore, the authors think that the filling effect of nano-VS might be more obvious in the concretes of relatively high $\mathrm{w} / \mathrm{b}$ ratios. Nonetheless, further investigation is recommended in this direction. Further, as can be clearly seen in Fig. 14, the highest positive DI values (i.e. more than 1.7) were recorded when nano-VS content was added either at $3 \%$ or $4 \%$.

\subsection{Microstructural analysis}

The investigated paste samples were micro structurally examined by Scanning Electron Microscope (SEM, VEGA II TESCAN) fitted with energy dispersive X-ray spectroscopy (EDS, EDAX AMETEK) after being dried, fragmented and rinsed with acetone. Figure 15 shows the SEM micrographs of the pastes prepared with $\mathrm{w} / \mathrm{b}=0.6$ and cured for 7 days. A non-compacted structure with a relatively high porosity can be detected in the control sample as shown in Fig. 15a. On the other hand, more compacted structure with fewer $\mathrm{CH}$ crystals and limited voids is detectable in each of the nanoVS3-based paste and nano-VS5-based paste, Fig. 15b, c. This significant improvement can be due to the more $\mathrm{C}-\mathrm{S}-\mathrm{H}$ and $\mathrm{C}-\mathrm{A}-\mathrm{S}-\mathrm{H}$ compounds, formed by the pozzolanic reaction occurring between the vitrified phase of nano-VS and the portlandite $(\mathrm{CH})$ produced during the hydration of cement components, namely $\mathrm{C} 3 \mathrm{~S}$ and C2S. Further, a lower quantity of $\mathrm{CH}$ crystals can be seen in the pastes containing nano-VS3 and nano-VS5 when compared with that of zero nano-VS content. Furthermore, cementing compounds of relatively low $\mathrm{Ca} / \mathrm{Si}$ ratio can be noted in the nano-VS3-based paste, Fig. 15 (b). Formation of such compounds may result in having concrete of less permeable and thus more durable [43]. This 
Fig. 11 Relative CIP results of the concretes made with different $\mathrm{w} / \mathrm{b}$ ratios and cured for five different curing ages
Fig. 12 Relationships among the permeability properties of the investigated concretes prepared with nano-VS

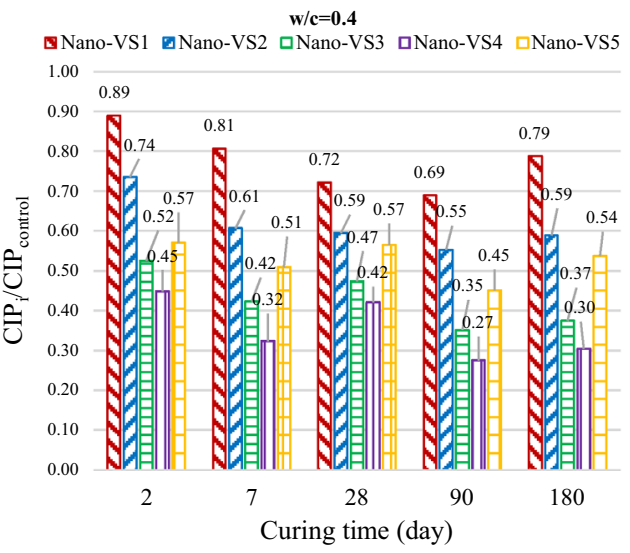

(a) Nano-VS $(\mathrm{w} / \mathrm{b}=0.4)$

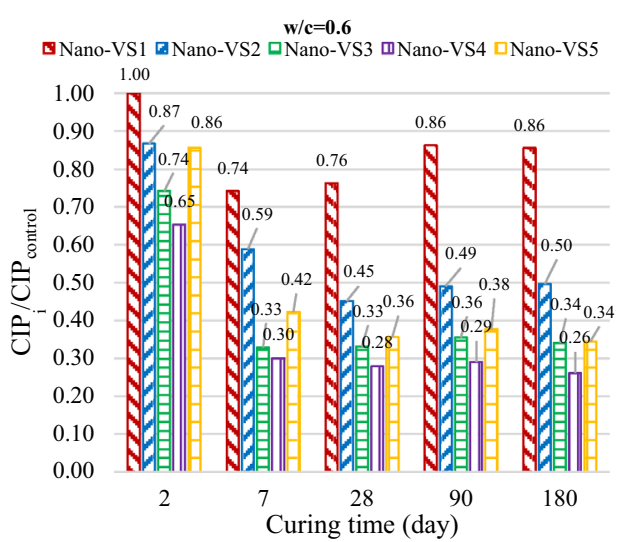

(c) Nano-VS $(\mathrm{w} / \mathrm{b}=0.6)$

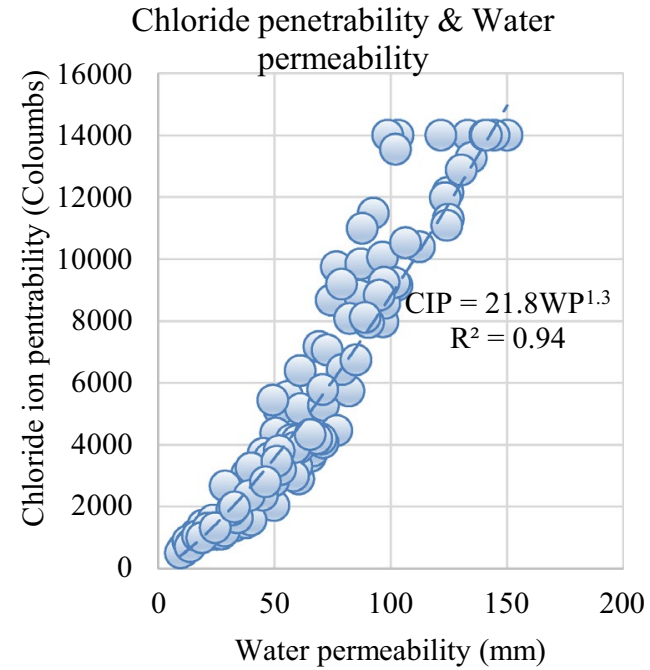

(a)

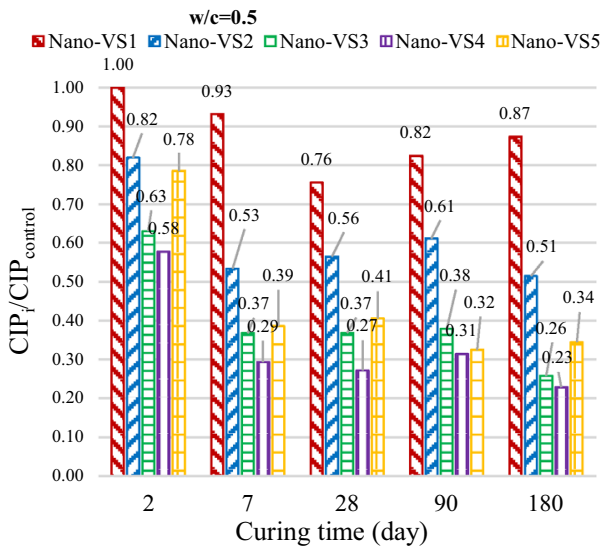

(b) Nano-VS $(\mathrm{w} / \mathrm{b}=0.5)$

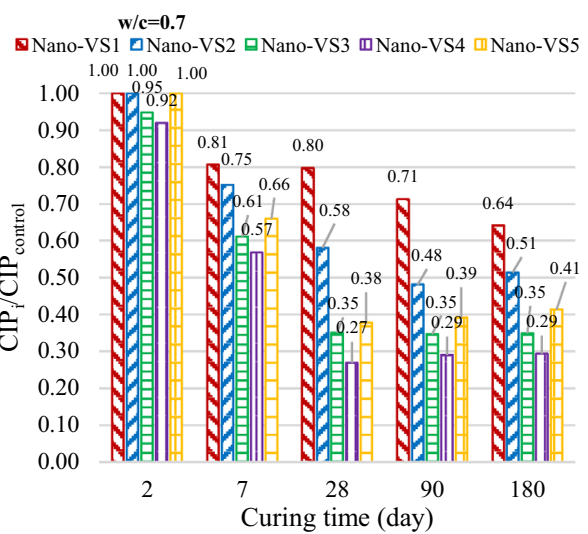

(d) Nano-VS (w/b=0.7)

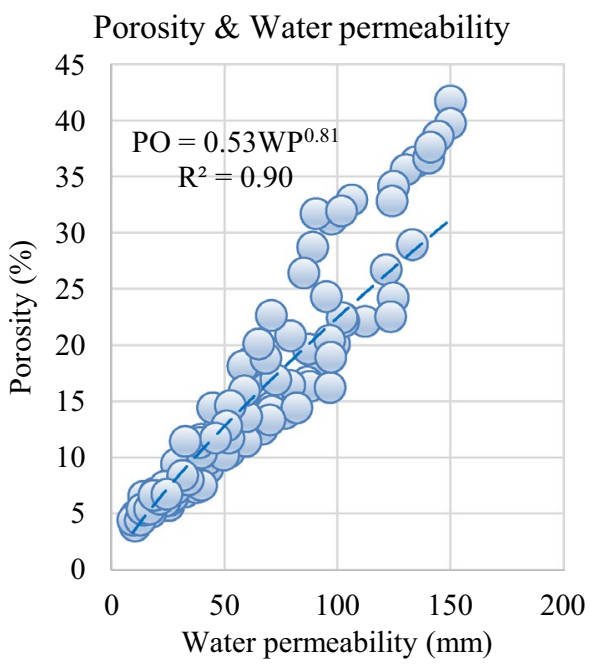

(b) was practically confirmed by the results obtained when nano-VS3-based concretes were tested under either water or chloride ion penetration, as obviously seen in Figs. 6 and 10, respectively.

\subsection{Cost-effectiveness of the investigated nano-VS}

The high initial cost of using nano-particles still represents a big Challenge. Although, the preparation cost of the investigated nano-VS was relatively high, i.e. about $\$ 45 /$ 


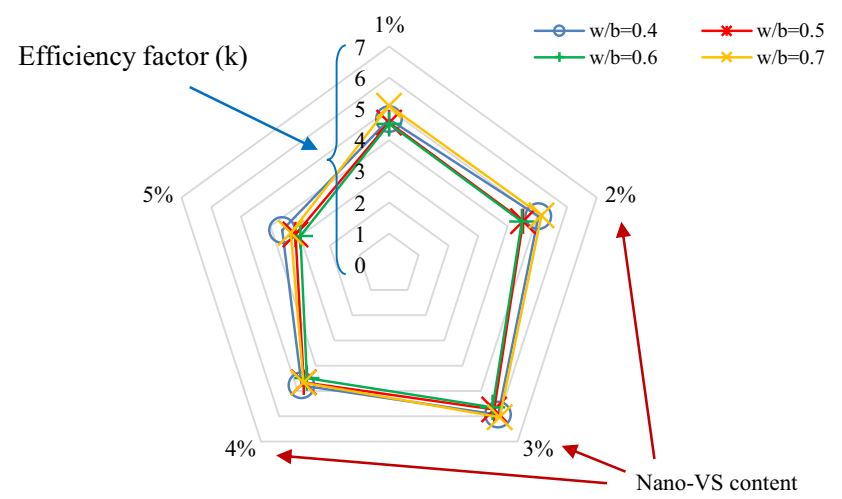

Fig. 13 Efficiency factors of VS-based binder concretes cured for 28 days at different $w / b$ ratios

Table 2 Constants $a_{1}, a_{2}, a_{3}$ and $a_{4}$ and $R^{2}$ values of the relationship between the experimental and calculated efficiency factors based on the derived equation

\begin{tabular}{lcllll}
\hline $\mathrm{w} / \mathrm{b}$ & \multicolumn{2}{l}{ Constants } & $\mathrm{R}^{2}$ \\
\cline { 2 - 5 } & $\mathrm{a}_{1}$ & $\mathrm{a}_{2}$ & $\mathrm{a}_{3}$ & $\mathrm{a}_{4}$ & \\
\hline 0.4 & 4.56 & -0.9296 & -31.977 & 6.8028 & 0.89 \\
0.5 & -0.85 & -0.5963 & -10.652 & 5.4786 & 0.82 \\
0.6 & 1.9 & -0.7144 & -20.172 & 5.8112 & 0.91 \\
0.7 & 4.78 & -0.7788 & -33.871 & 5.9765 & 0.96 \\
\hline
\end{tabular}

$\mathrm{kg}$, but this figure can be considered reasonable for the following:

(1) Nano-VS was prepared, in the current study, in small quantities and at a laboratory scale.
(2) Higher costs were reported in literature, for instance, the cost of one Kilogram of nano- $\mathrm{Al}_{2} \mathrm{O}_{3}$ was about $\$ 100[44]$.

(3) The figure covers the mill balls wearing, the electricity consumption costs during sample grinding and the particle dispersing process.

On the other hand, the application of nano-VS on a large scale and the reduction of rehabilitation costs due to the improved properties offered by nano-VS would make it more cost-effective in the long-term [45].

\section{Conclusion}

The application of nano-VS can be considered as emerging areas of interest in the countries where many scoria cones are available.

This paper points out the following:

1. The workability of fresh concrete was markedly affected by adding nano-VS at high replacement levels. About $15 \%$ decrease in slump values were observed when $5 \%$ nano-VS was added.

2. The delay in compressive strength, which is associated with the use of micro-VS, can be overcome by adding VS at a non-scale even at small dosage. Hence, study on using both micro and nano-VS is highly recommended.

3. The permeability properties of concrete can be significantly reduced by adding nano-VS even at small dosages.

4. The binders containing nano-VS content of 3 or $4 \%$ performed the best among all other binders taking
Fig. 14 Durability indicators of concretes containing different volcanic scoria contents cured for 28 days when all investigated properties were taken into account (SD values ranged from 0.03 to 0.09 )

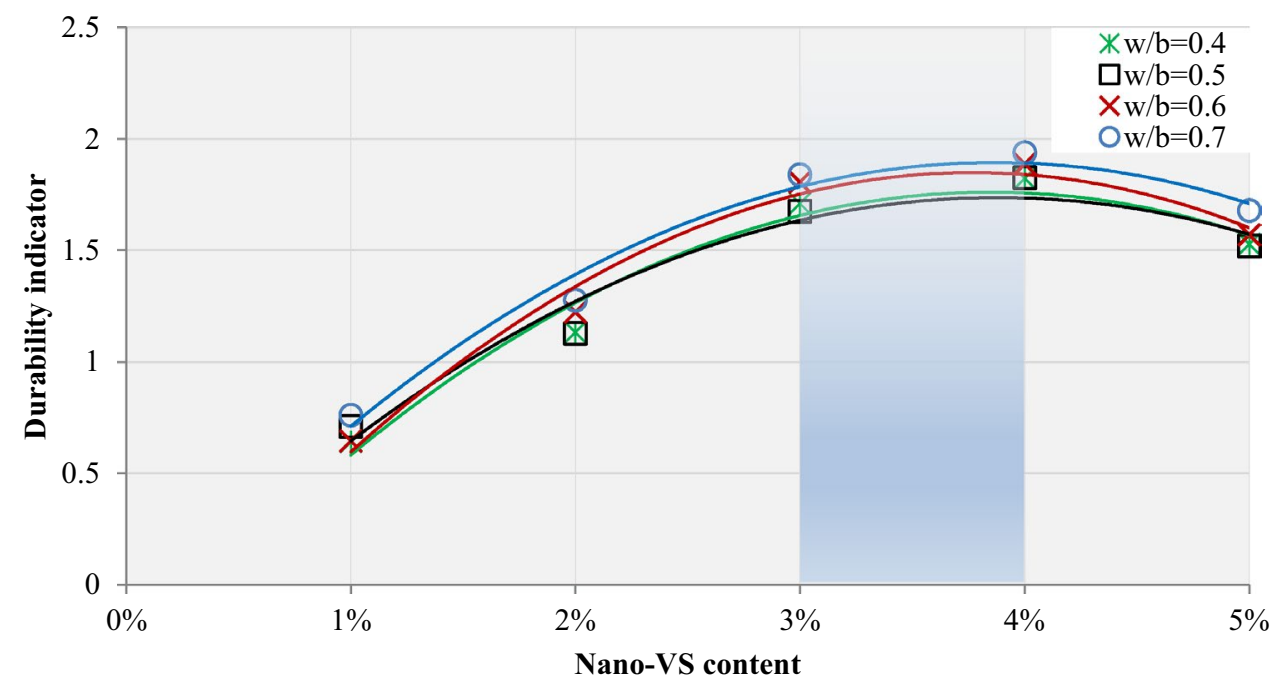




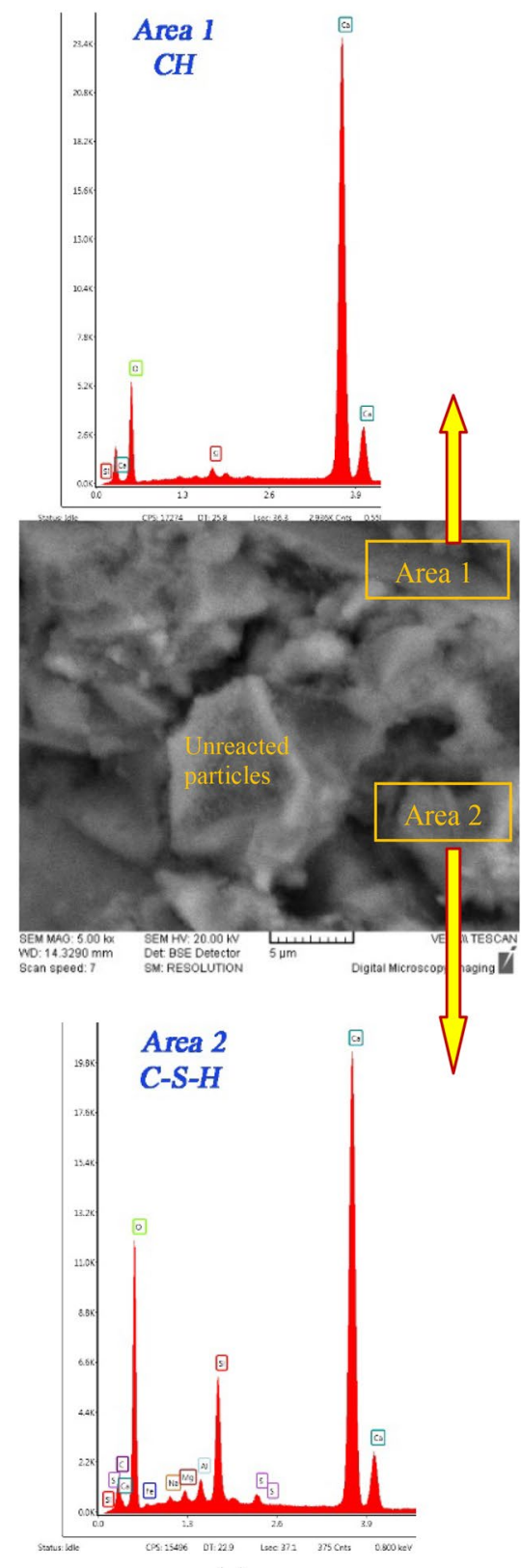

(a)

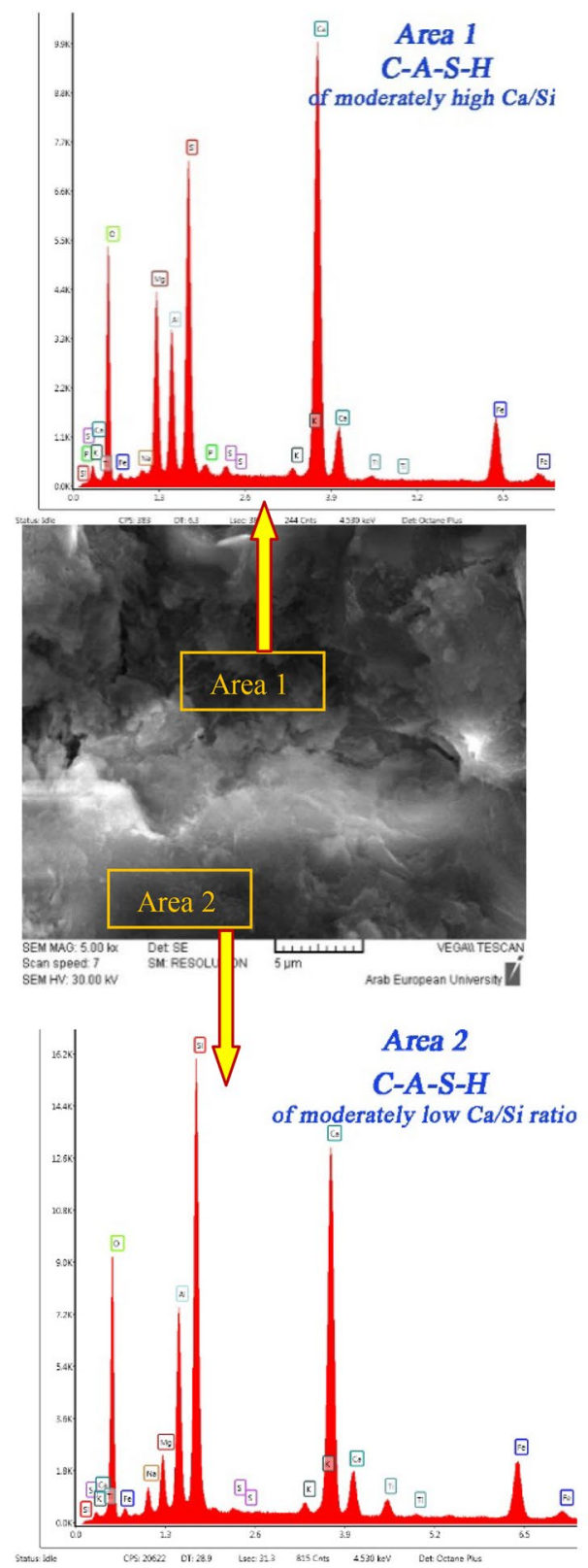

(b)

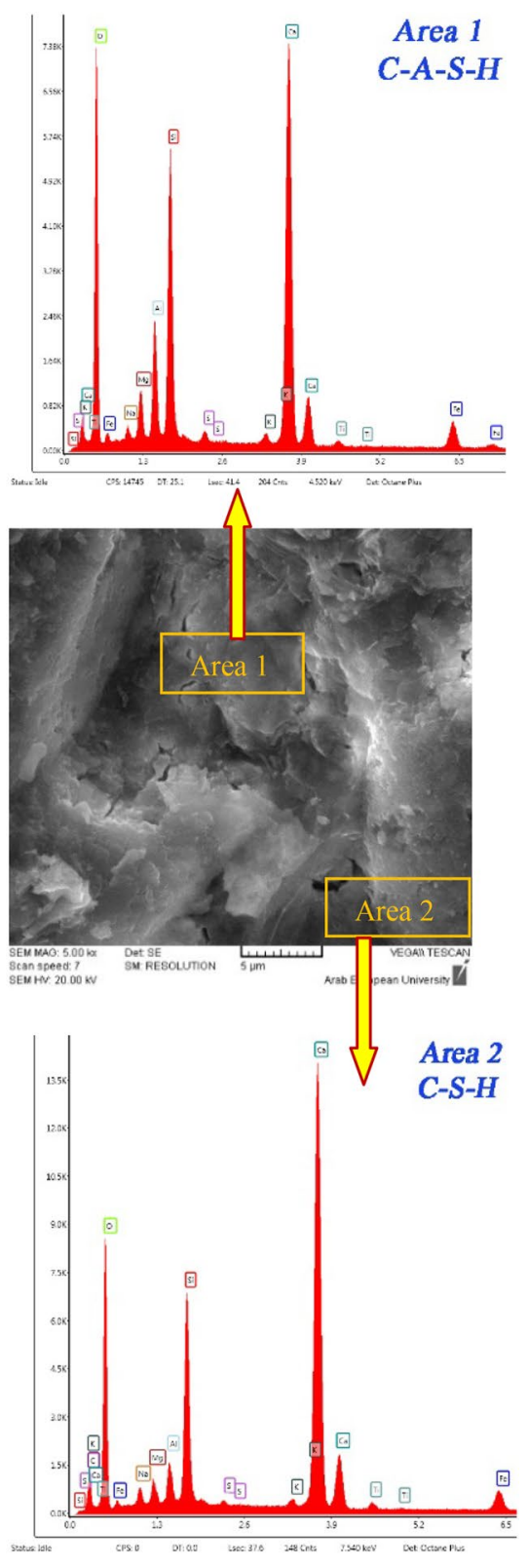

(c)

Fig. 15 Scanning electron micrographs ( $\times 5000)$ with EDS analysis of a control paste (nano-VS0), $\mathbf{b}$ and c nano-VS3- and nano-VS5-containing pastes, respectively, cured for 7 day

into account the permeability properties, i.e. water permeability, porosity and chloride ion penetrability. K-value of about 4.6 (for $4 \%$ replacement level irrespective of the $\mathrm{w} / \mathrm{b}$ ratio) can be considered helpful in a future eco-friendly concrete mix design.

5. An attempt to derive a prediction formula for estimating the efficiency factor, i.e. $k$, was supplied by the author. The effect of curing age and nano-VS content were considered in this estimation. This formula gives a relatively accurate prediction $\left(R^{2} \geq 0.82\right)$ of the efficiency factor at all $\mathrm{w} / \mathrm{b}$ ratios.

6. SEM analysis showed notable densification in the cement paste containing nano-VS. The microstructure of the cement paste containing nano-VS revealed a dense, compact formation of hydration products and a reduced number of $\mathrm{CH}$ crystals.

7. Unexplored volcanic scoria cones could be a matter of attraction to the makers of more durable and sustain- 
able concretes, particularly when VS is added at micro and nano-scale.

8. Addition of nano-VS can be considered a promising approach. However, some properties need to be further checked.

\section{Compliance with ethical standards}

Conflict of interest There is no conflict of interest.

\section{References}

1. al-Swaidani AM, Aliyan SD (2015) Effect of adding scoria as cement replacement on durability-related properties. Int J Concr Struct Mater 9:241-254. https://doi.org/10.1007/s4006 9-015-0101-z

2. Ozvan A, Tapan M, Erik O, Efe T, Depci T (2012) Compressive strength of scoria added portland cement. Gazi Univ J Sci 25(3):769-775

3. Asiabanha A, Bardintzeff JM, Sara Veysi S (2017) North Qorveh volcanic field, western Iran: eruption styles, petrology and geological setting. DOI, Mineral Petrol. https://doi.org/10.1007/ s00710-017-0541-z

4. Khan Ml, Alhozaimy (2011) Properties of natural pozzolan and its potential utilization in environmental friendly concrete. Can J Civ Eng 38:71-78. https://doi.org/10.1139/L10-112

5. Tchamdjoua WHJ, Grigolettoc S, Michelc F, Courardc L, Abidia ML, Cherradia T (2017) An investigation on the use of coarse volcanic scoria as sand in Portland cement mortar. Case Stud Constr Mater 7:191-206. https://doi.org/10.1016/j.cscm.2017.07.005

6. Siegbug M, Gernon TM, Bull JM, Keir D, Barfod DN, Taylor RN et al (2018) Geological evolution of the Boset-Bericha volcanic complex, main Ethiopian Rift: 40Ar/39Ar evidence for episodic Pleistocene to Holocene volcanism. J Volcanol Geotherm Res 351:115-133. https://doi.org/10.1016/j.volgeores.2017.12.014

7. Al-Zboon KK, Al-Zou'by J (2015) Effect of volcanic tuff on the characteristics of cement mortar. Eur J Environ Civ Eng. https:// doi.org/10.1080/19648189.2015.1053151

8. Senhadji Y, Escadeillas G, Mouli M, Khelafi H, Benosman (2014) Influence of natural pozzolan, silica fume and limestone fine on strength, acid resistance and microstructure of mortar. Powder Technol 254:314-323. https://doi.org/10.1016/j.powte c.2014.01.046

9. Traglia FD, Cimarelli C, de Rita D, Torrente DG (2009) Changing eruptive styles in basaltic explosive volcanism: examples from Croscat complex scoria cone, Garrotxa Volcanic Field (NE Iberian Peninsula). J Volcanol Geotherm Res 180(2009):89-109. https:// doi.org/10.1016/j.jvolgeores.2008.10.020

10. Erlund EJ, Cashman KV, Wallace PJ, Pioli L, Rosi M, Johnson E, Granados HD (2009) Compositional evolution of magma from Paricutin Volcano, Mexico: the tephra record. J Volcanol Geotherm Res. https://doi.org/10.1016/j.jvolgeores.2009.09.015

11. Al-Swaidani A (2018) Volcanic scoria as cement replacement. In: Aeillo G (ed) "Volcanoes". Intechopen, UK. https://doi. org/10.5772/intechopen.77970

12. Al-Swaidani AM (2016) Prediction of compressive strength and some permeability-related properties of concretes containing volcanic scoria as cement replacement. Rom J Mater 46(4):505-514

SN Applied Sciences

APRINGER NATURE journa
13. Said AM, Zeidan MS, Bassouni MT, Tian Y (2012) Properties of concrete incorporating nano-silica. Constr Build Mater 36:838844. https://doi.org/10.1016/j.conbuildmat.2012.06.044

14. Hakamy A, Shaikh FUA, Low IM (2015) Characteristics of nanoclay and calcinednanoclay-cement nanocomposites. Compos B 78:174-184. https://doi.org/10.1016/j.compositesb.2015.03.074

15. Nazari A, Riahi S (2011) Improvement compressive strength of concrete in different curing media by $\mathrm{Al}_{2} \mathrm{O}_{3}$ nanoparticles. Mater Sci Eng A 528:1183-1191. https://doi.org/10.1016/j. msea.2010.09.098

16. Oltulu $\mathrm{M}$, Sahin $\mathrm{R}$ (2013) Effect of nano-SiO ${ }_{2}$, nano- $\mathrm{Al}_{2} \mathrm{O}_{3}$ and nano- $\mathrm{Fe}_{2} \mathrm{O}_{3}$ powders on compressive strengths and capillary water absorption of cement mortar containing fly ash: a comparative study. Energy Build 58:292-301. https://doi. org/10.1016/j.enbuild.2012.12.014

17. Morsy MS, Alsayed SH, Aqel M (2011) Hybrid effect of carbon nanotube and nano-clay on physic-mechanical properties of cement mortar. Constr Build Mater 25(1):145-149. https://doi. org/10.1016/j.conbuildmat.2010.06.046

18. Qing Y, Zenan Z, Deyu K, Rongshen C (2007) Influence of nano$\mathrm{SiO}_{2}$ addition on properties of hardened cement paste as compared with silica fume. Constr Build Mater 21(3):539-545. https ://doi.org/10.1016/j.conbuildmat.2005.09.001

19. Zhang $\mathrm{MH}$, Li H (2011) Pore structure and chloride permeability of concrete containing nano-particles for pavement. Constr Build Mater 25:608-616. https://doi.org/10.1016/j.conbuildma t.2010.07.032

20. Atahan HN, Dikme D (2011) Use of mineral admixtures for enhanced resistance against sulphate attack. Constr Build Mater 25:3450-3457

21. Atahan HN, Arslan KM (2016) Improved durability of cement mortars exposed to external sulfate attack: The role of nano \& micro additives. Sustain Cities Soc

22. Singh LP, Karade SR, Bhattacharyya SK, Yousuf MM, Ahlawat $S$ (2013) Beneficial role of nano-silica in cement based materials- a review. Constr Build Mater 44:1069-1077

23. Shebl S, Allie L, Morsy M, Aglan H (2009) Mechanical behaviour of activated nano silicate filled cement binders. J Mater Sci 44(6):1600-1666. https://doi.org/10.1007/s10853-008-3214-9

24. Nazari A, Riahi S (2010) the effects of $\mathrm{TiO}_{2}$ nanoparticles on properties of binary blended concrete. J Compos Mater. https://doi. org/10.1177/0021998310378910

25. Sneff L, Hotza D, Repette WL, Ferreira VM, Labrincha JA (2009) Influence of added nanosilica and/or silica fume on fresh and hardened properties of mortars and cement pastes. Adv Appl Ceram 108(7):418-428. https://doi.org/10.1179/174367609X 422108

26. Ferraris $\mathrm{CF}$, Obla $\mathrm{KH}$, Hill R (2001) The The influence of mineral admixtures on the rheology of cement paste and concrete. Cem Concr Res 31(2):245-255. https://doi.org/10.1016/S0008 -8846(00)00454-3

27. Jo BW, Kim CH, Tae G, Park JB (2007) Characteristics of cement mortar with nano- $\mathrm{SiO}_{2}$ particles. Constr Build Mater 21:13511355. https://doi.org/10.1016/j.conbuildmat.2005.12.020

28. Li H, Xiao H, Yuan J, Ou J (2004) Microstructure of cement mortar with nano-particles. Compos B 35:185-189. https:// doi.org/10.1016/S1359-8368(03)00052-0

29. Smith IA (1967) The design of fly ash concretes. Proc-Inst Civ Eng Lond 36:770-789

30. Thomas MDA, Matthews JD (1994) Durability of PFA concrete. BRE report BR216. Building Research Establishment, Watford

31. Babu KG, Rao GSN (1993) Efficiency of fly ash in concrete. Cem Concr Compos 15:223-228. https://doi.org/10.1016/09589465(93)90025-5 
32. Sellevold EJ, Nilsen T (1997) Condensed silica fume in concrete: a world review. In: Supplementary cementing materials for concrete, edited by CANMET, Ottawa, pp 165-243

33. Tchamdjou WHJ, Grigoletto S, Michel F, Courard L, Cherradi T, Abidi ML (2017) Effects of various amounts of natural pozzolans from volcanic scoria on performance of Portland cement mortars. Int J Eng Res Afr 32:36-52. https://doi.org/10.4028/www. scientific.net/JERA.32.36

34. Pekmezci BY, Pekmezci BY, Akyuz S (2004) Optimum usage of a natural pozzolan for the maximum compressive strength of concrete. Cem Concr Res 34:2175-2179. https://doi.org/10.1016/j. cemconres.2004.02.008

35. Kaid N, Cyr M, Khelafi H (2015) Characterization of an Algeria natural pozzolan for its use in eco-efficient cement. Int J Civ Eng 13(4A):444-454. https://doi.org/10.22068/IJCE.13.4.444

36. Li H, Zhang M, Ou J (2006) Abrasion resistance of concrete containing nano-particles for pavement. Wear 260:1262-1266. https ://doi.org/10.1016/j.wear.2005.08.006

37. Farzadnia N, Noorvand $\mathrm{H}$, Yasin AM, Aziz FNA (2015) The effect of nano silica on short term drying shrinkage of POFA cement mortars. Constr Build Mater 95:636-646. https://doi.org/10.1016/j. conbuildmat.2015.07.132

38. Sneff L, Labrincha JA, Ferreira VM, Hotza D, Repette WL (2009) Effect of nano-silica on rheology and fresh properties of cement pastes and mortars. Constr Build Mater 23:2487-2491. https:// doi.org/10.1016/j.conbuildmat.2009.02.005

39. Neville A (2011) Properties of concrete, 5th edn. Pearson Education, London
40. Ghafari E, Costa H, Julio E, Portugal A, Duraes L (2014) The effect of nanosilica addition on flowability, strength and transport properties of ultra high performance concrete. Mater Des 59:1-9. https://doi.org/10.1016/j.matdes.2014.02.051

41. Chia KS, Zhang MH (2002) Water permeability and chloride penetrability of high-strength lightweight aggregate concrete. Cem Concr Res 32:639-645. https://doi.org/10.1016/S0008 -8846(01)00738-4

42. Montgomery DC, Peck EA (1982) Introduction to linear regression analysis. Wiley, New York

43. Kawashima S, Hou P, Corr DJ, Shah SP (2013) Modification of cement-based materials with nanoparticles. Cem Concr Compos 36:8-15. https://doi.org/10.1016/j.cemconcomp.2012.06.012

44. Skandan G, Singhal A (2006) Perspectives on the science and technology of nanoparticle synthesis. In: Gogotsi Yury (ed) Nanomaterials handbook. Taylor \& Francis Group, Routledge

45. Safiuddin M, Gonzalez M, Cao J, Tighe SL (2014) State of the art report on use of nano-materials in concrete. Int J Pavement Eng 10:12. https://doi.org/10.1080/10298436.2014.893327

Publisher's Note Springer Nature remains neutral with regard to jurisdictional claims in published maps and institutional affiliations. 